\title{
Garden-non-garden. Contemporary trends in transformation of greenery as an instrument in the contest for the city
}

\section{Beata J. Gawryszewska}

(Department of Landscape Art, Warsaw University of Life Sciences)

\begin{abstract}
The aim of the paper is to characterize contemporary transformation of urban greenery, which rely on the image of garden in order to arrive at a "garden-like" character of the cityscape. It also demonstrates how the image of garden is applied in the city as a new tool of social communication in the course of democratic transformation of the urban space. The author discusses the origins of the garden-image and the "garden-like" character of space, providing examples of how it is used today in the cityscape by the inhabitants, activists, designers and artists. The text introduces a range of informal, Polish projects of urban gardens and spaces drawing on its image, describing their novel role in building the vernacular landscape of a city.
\end{abstract}

Key words

Activism, cityscape, landscape architecture, urban garden

The garden, though seemingly associated with suburban areas, now sees a revival of its popularity in European cities. Thanks to the post-modern departure from the anthropocentric vision of the natural environment of human habitation, the garden gains a new dimension in a range of aspects. Firstly, the contemporary urban garden is being defined anew, because both the place in which it emerges and the needs it caters to have undergone substantial changes. Secondly, the previous role and the character of urban greenery already suffered a major crisis in the midtwentieth century, when the large-surface open areas in housing developments so ardently advocated for by modernists not only began to be criticized by postmodern theorists and designers, but also lost value in the eyes of their residents, 
who did not hesitate to transform them as they saw fit-converting the anonymous green areas, so far devoid of cultural context, into sites that possessed individuality. Lending new aspects to space, they drew on a tradition of the image of a garden that went back to the roots of European culture (Gawryszewska 2004).

As the title suggests, my objective here is to outline the transformations of greenery that relied on the image of a garden to forge a "garden-like" character within cities and, at the same time, show how the garden image in a cityscape has been employed as a new tool of social communication in the process of democratic changes to urban spaces. Below, I discuss the origins of the garden image and the "garden-like" nature of space, subsequently quoting successive examples of its use in contemporary landscape, be it by the inhabitants, urban activists, or designers and artists.

In the text, I refer to instances of informal urban garden projects and spaces invoking the garden image in Poland, and I endeavor to describe their new role in constructing the vernacular landscape of the city. The undertakings are a material manifestation of inhabitants assuming responsibility for urban space and exercising the community's entitlement to the most obvious resource of a modern city (i.e., open space). This kind of action, seen from the standpoint of critical post-humanism, enacts a reality in which we co-exist with other beings - on behalf of human and non-human subjects which function in it (Latour 2009). In his famed Rebel Cities: From the Right to the City to the Urban Revolution, David Harvey (2012, 3-5) interpreted the manners in which residents enforce that right as answers to questions concerning such issues as re-evaluation of social relationships, the anticipated modification of recognized aesthetic values, as well as the desired change of people's lifestyle and of their approach to natural environment.

\section{The image of a garden as a chosen place}

One hears at times that the biblical Paradise was a conceptual, and even formal, prototype of a garden. And although such notions may seem anachronic today, the comparison of a garden to paradise is still legitimate when one considers its representation and the inseparable context of the earthly world-that is, noticing that the experience of the extraordinariness of the garden is utterly impossible without reference to the mundanity of its surroundings.

In the Mediterranean tradition, to which we owe our contemporary notion of it, the garden is described as a particular place found in the landscape-selected, surrounded with a wall or hedge, and divided into sections for ease of cultivating specific plants (de Crescendis 1549). The topos of the garden described in the tradition is an idealized space, diametrically distinct from the landscape outside its bounds (Rymkiewicz 2010). The garden has to stand out against the landscape by 
virtue of its unequivocally identified image. It is made up of a repertoire of forms which establish a particular "garden-like" character.

Usually, the garden connotes a private space, however when one examines the structure of space attached to sites of habitation, be it in detached development or housing estates, where strictly private space is hard to come by, one notices that the image of the garden arises from the practices of usage and arrangement (Gawryszewska 2013). Apparently, this is the upshot of the innate human need to build surroundings which correspond to the notions of ideal, virgin nature that are simultaneously devoid of the wildness that represents a potential source of danger (Assunto 2015). Still, does it have to be beautiful?

In 2012, working in collaboration with Izabela Myszka-Stąpór, we created a traditional countryside garden, established by way of experiment at the Arboretum of Bolestraszyce near Przemyśl (Myszka-Stąpór and Gawryszewska 2013). Our experiment consisted in arranging the garden using plants available in the area, following a pragmatics of composition dictated by cultivation and consulting local inhabitants. Both the latter and the visitors to the arboretum would recall the gardens of their mothers, grandmothers, and aunts while watching us work, and then readily shared their memories. One by one, they enumerated the names of plants they felt were indispensable to arrive at an image of a "true garden": roses, nightscented stocks, pot marigolds, marigolds, tulips, primroses, irises, coneflowers, sneezeweeds, sunflowers, phloxes, and hollyhocks, obviously. The lists of plants proved repeatedly consistent, not only in conversations but also in the findings from an inventory taken in dozens of contemporary gardens carried out myself to determine the model image of a household garden (Gawryszewska 2013). It also included food crops (i.e., trees and shrubs bearing fruit, vegetables, and herbs). Interestingly enough, the respondents did not mention views or sophisticated compositional patterns, nor did they speak of how they spent time in the gardens of their childhood; they merely recalled its image.

Thus, the fundamental elements that make up the image of a garden are blooming plants: annuals, biennials, perennials, as well as fruit trees and shrubs, vegetables, and herbs. The garden plants are treated subjectively, and the gardenersestablish individual relationships with them (Gawryszewska 2013, 33, 43); therefore, one seldom encounters larger surfaces planted with the same species. The characteristic mosaic of colors and forms are obtained by planting single or only several specimens at a time (Gawryszewskaand Myszka-Stąpór 2016). In Europe, especially in front gardens, the same set of plant types have been kept since at least the Middle Ages, and it is thanks to that selection that the garden image becomes recognizable. Said assortment, particularly blooming garden plants from the rose and aster families, is so important that in the case of unfavorable conditions, difficulties in cultivation, shortage of time, etc., creators of gardens resort to artificial flowers (Winiarska-Lisiecka 2016). Artificial roses, lilies, asters, and narcissuses 
are encountered where the "garden-like" character of a place is so entrenched in the tradition that it cannot do without them-for instance, at the shrines in courtyards of urban tenement houses (Gawryszewska 2013, 106).

In the contemporary city, actions aimed at distinguishing a site in space often boil down to its being decorated with flowers, which brings the concept of gardens to mind. Such non-gardens, flowerbeds which nevertheless invoke the image of a garden, are seen underneath windows of blocks of flats and in the courtyards of tenements. They replace neglected lawns, to indicate that a space has been taken possession of and a meaningful place has been created. They are a message communicating habitation, addressed to neighbors and passers-by, distinguishing a placethat has an owner/gardener from a space that belongs to nobody.

\section{Fig. 1}

"Garden-like" character with which a space is endowed by drawing on the image of a household garden

\section{A}

Kalwaria garden, Arboretum in Bolestraszyce (Poland), arranged in accordance with how a traditional farmhouse/cottage garden is envisioned

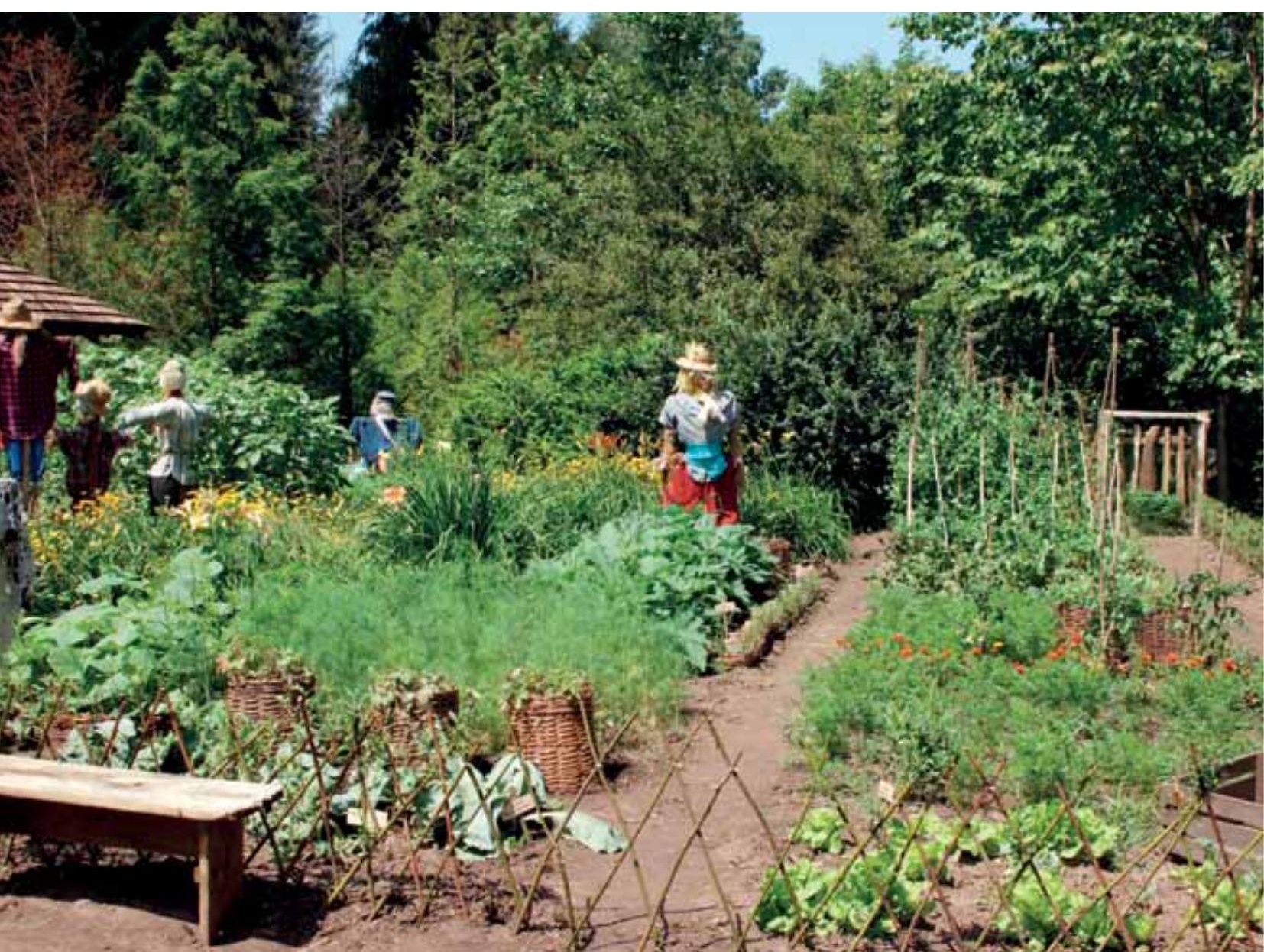




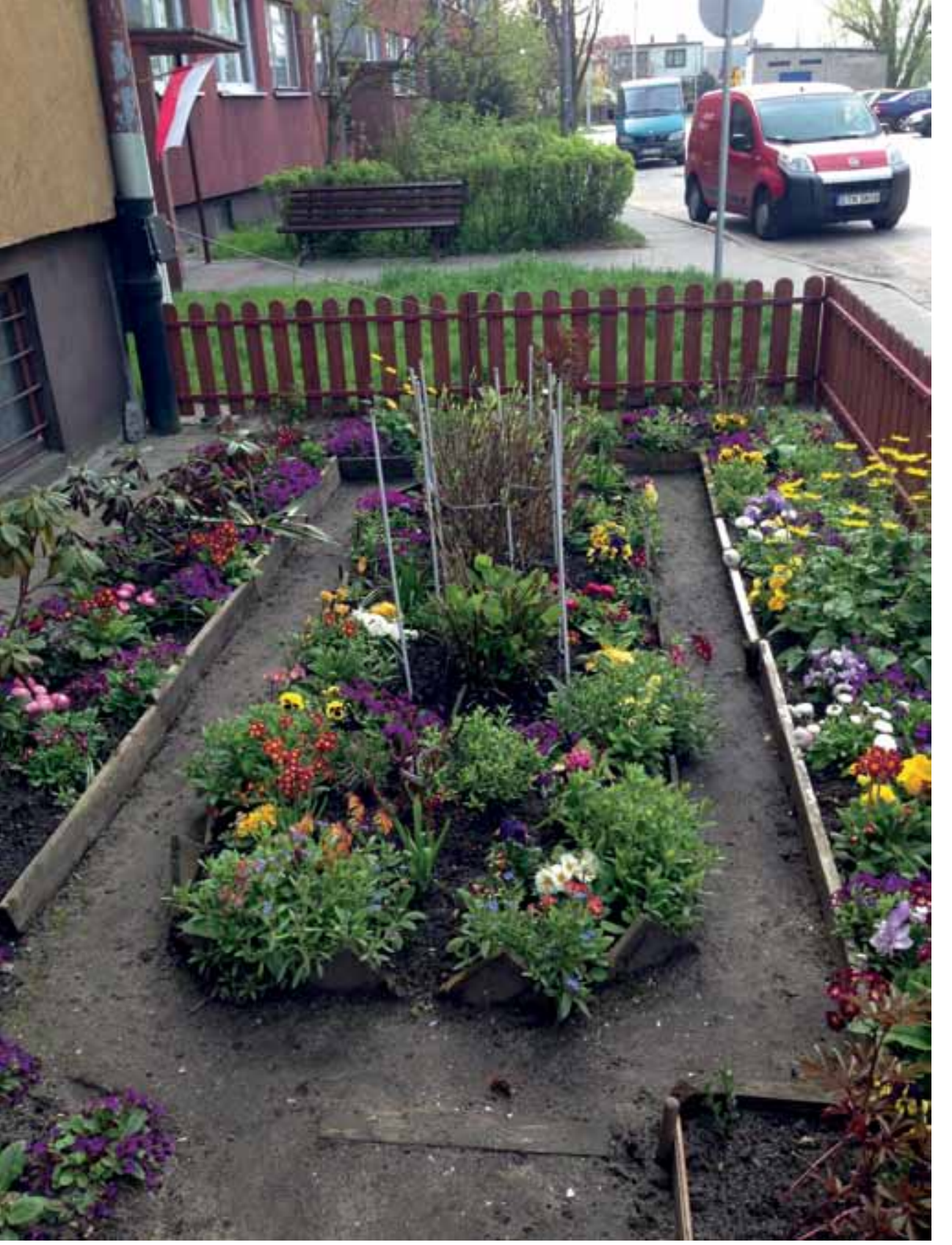

Fig. 1B

Mini-garden under a window of a block of flats in Tomaszów Mazowiecki (Poland) 


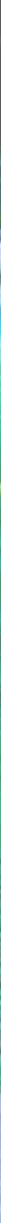

Fig. 1C

Flowerbed created by residents of Chomiczówka in Warsaw 


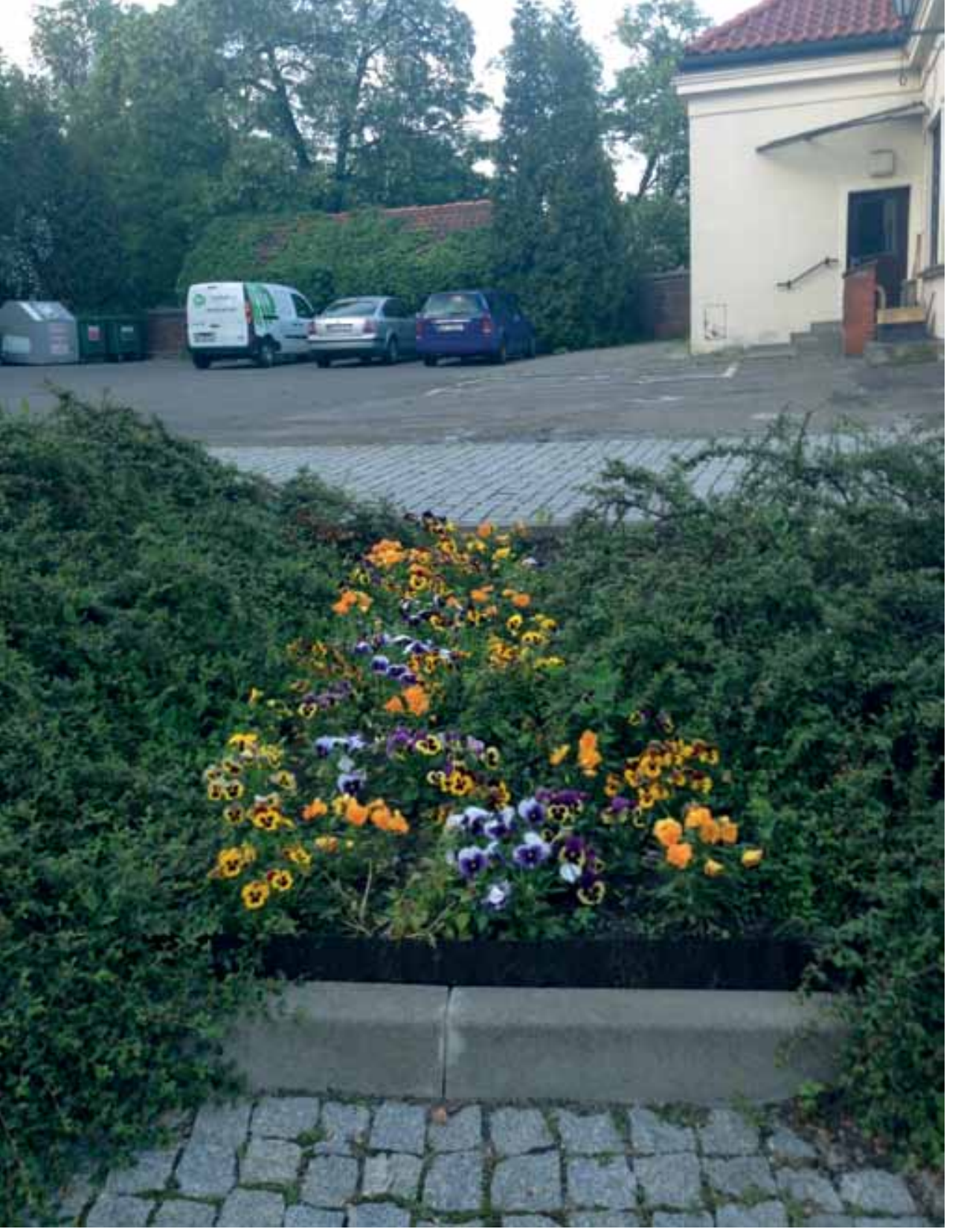

Fig. 1D

Flowerbed planted on a footpath created by people taking a shortcut, courtyard of the University of Warsaw complex on Krakowskie Przedmieście in Warsaw 


\section{The garden as an attribute of a committed landscape}

The erstwhile, medieval image of agarden - where it had been a site of cultivation, a place where the gardener toiled and everyday bustle took place-transitioned in the age of Renaissance villas of the Seicento into garden-views, designed as perspective-based vistas, geometricized and wholly subordinated to the experience of beauty from an "elevated place," such as a balcony-loggia or a terrace built specially for that purpose (Szafrańska 2011). In the sixteenth century, the garden became first and foremost a visual feature. Francesco de Vieri writes about the garden exclusively as a "piece to be gazed at" (quoted in Szafrańska 2011, 14). This duality of the garden's function may be observed in today's cities; the formalized arrangements of urban greenery laid out by certified architects are a counterpart to vernacular gardens cultivated by inhabitants and urban activists, which have more to do with a performative pleasure of working in a garden than a fancy sight. I discussed garden as a performance jointly with Łukasz Guzek in 2002, comparing cultivation of plants and being among them to performance art. Just like the artistic discipline, gardening is an individualistic action in space. Its form is a personal projection in that it results from idiosyncratic traits of the individual practitioner. It has an author, an inimitable character, and it is anchored in culture. The aim of being in a garden and creating it is the process itself rather than its outcome (Gawryszewska and Guzek 2002). It is approached in a similar manner by Mateusz Salwa, who remarks on the event-like character of the garden, both in terms of human action and the actions of nature itself. Thus, Salwa classifies the performative aspect of the garden as a trait indicative of the post-humanist performative shift in contemporary humanities (Salwa 2016, 173). Elsewhere, Salwa draws on Amadeo Bellini (1992) to describe the garden as an open-ended work which never reaches completion.

In line with Berleant's aesthetics of engagement, establishing and cultivating a garden entails anaesthetic experience-which consists in a daily sense of continuity with the landscape that is owed to any action in the garden, including taking care of it (Berleant 1997). Seeing the garden as a process, which tallies with the processual and at the same time participatory context of contemporary urban planning, is not unknown to theorists of green design. Martin Prominski writes about open design which, having delineated the general frame of space, leaves users free rein to lend individual character, appearance, and new meanings to a place (Prominski 2005,3 ). Is such an effect indeed achieved in public space, in the everyday landscape moldedby city dwellers through participation? The answer to the question may be found in community gardens, green interventions taking place throughout Europe at abandoned and unkept sites, with the essential aim of building and integrating a gardening community around them (Foster 2016). They may be initiated and established by social workers or activists, as in the case of the garden attached 
to the Służew Centre for Culture or the community garden on Aleja Solidarności in the Warsaw borough of Praga. Most often, however, community gardens are the upshot of grassroots initiatives. Some good examples of such undertakings include "Motyka i Słońce [The hoe and the sun]" or "Ogród Królowej Bony [Queen Bona’s garden]" in the Warsaw housing development of Jazdów, where the commitment of activists from social organizations prevented the demolition of a reminder of the post-war history of the city-a collection of Finnish wooden bungalows-and led to the establishment of a publicly accessible park in which numerous NGOs set up their premises. Here, community gardens are a sign communicating that control of an area has been taken over; they are not intended to accomplish any specific aesthetic effect but rather to be jointly cultivated. The fact that their creators employed the image of a garden was intended to network all those who were willing to join the community. As part of the struggle for the city, inhabitants endow urban space with a "garden-like" character and thus reclaim gardens as places of their habitation otherwise shackled by administrative dictate.

Nasz Park in Kabaty, Warsaw-formerly a neglected stretch of lawn between the entrance to the station of the underground and the nearby blocks of flatsachieves a similar goal. Led by their neighbor, local residents decided to transform it into a garden, planting trees, shrubs, and flowerbeds to be able to spend time there. Gradually, more and more were planted in the process, while further small "gardens" cropped up around the "park."

The paradise established by the anarchist organization known as Reclaim the Fields Poland, which may be found hidden in the dense greenery of a disused plot on ul. Bartycka in Warsaw, is an example of a garden-process that set out from a political agenda, a fact its creators do not deny. At the site of former allotment gardens, the activists built a self-sufficient complex with a wind turbine, ${ }^{1}$ bread oven, tool sheds, a point where goods may be exchanged free of charge and, naturally, beds of vegetables, herbs, and flowers. When interviewed, they stated they wished to prepare for the impending, new socio-economic realities, therefore they endeavored to create a garden and to gather a community of participants who wanted to learn how to manage resources and produce food responsibly and locally.

1 The turbine was dismantled in the summer of 2016, following a complaint lodged with city authorities by an investor who built a housing development there. 


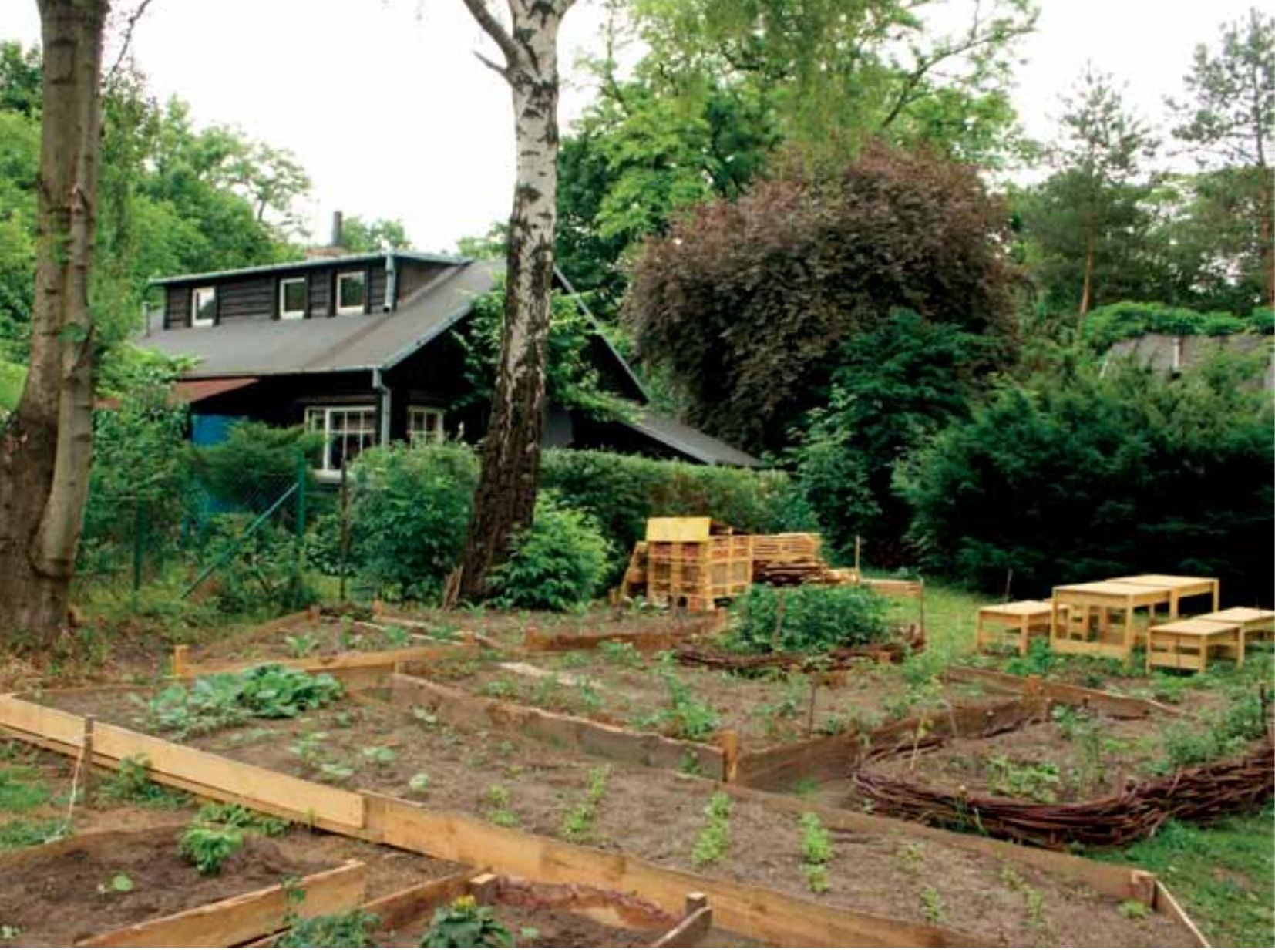

Fig. 2

Community gardens in Warsaw (Poland)

A

Motyka i Słońce (The Hoe and the Sun), run by the Workshop of Shared Goods in Jazdów, Warsaw 


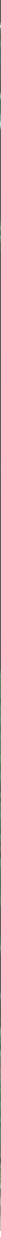

Fig. 2C

Nasz Park (Our Park) in the Kabaty district of Warsaw 


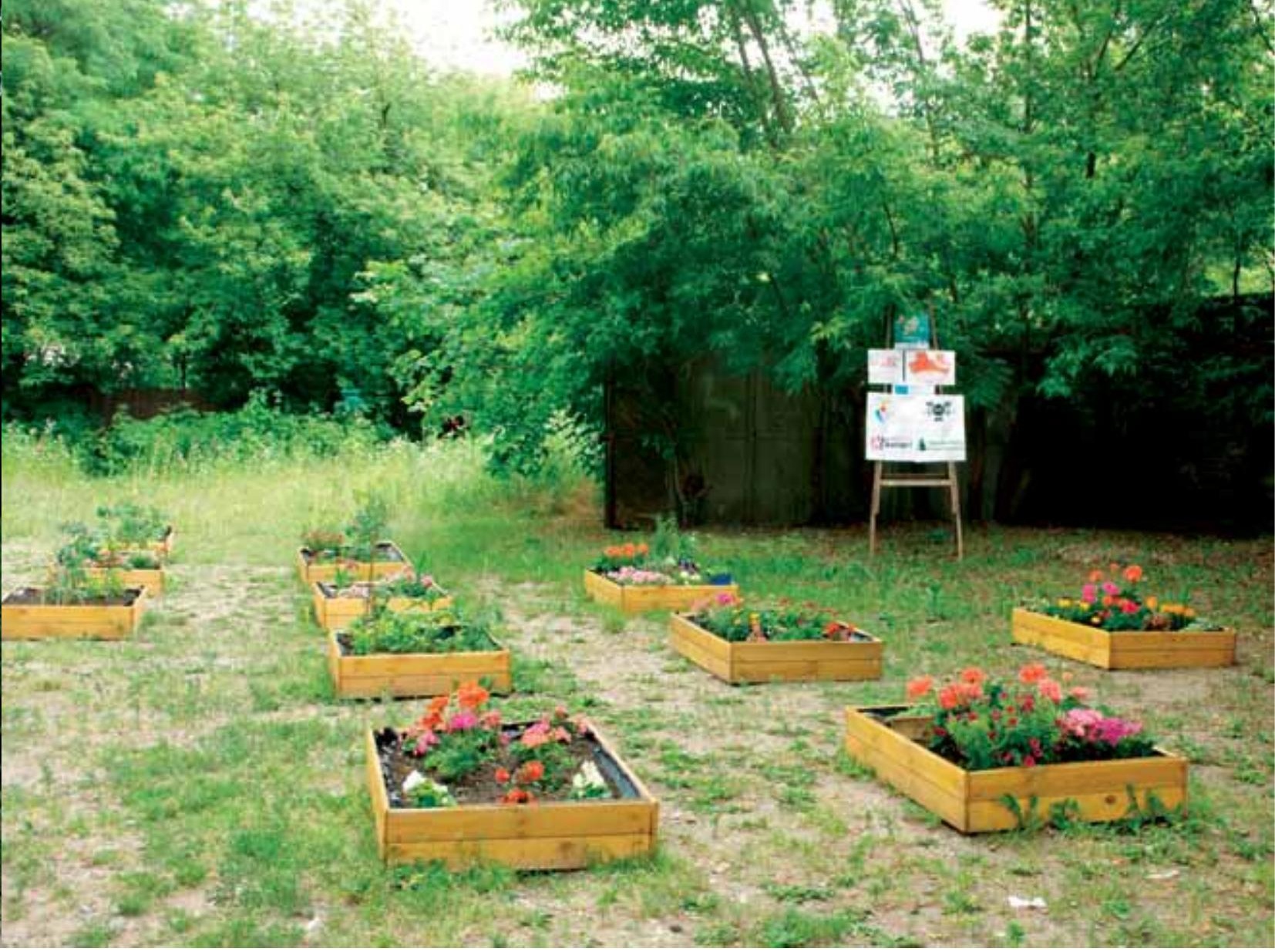

Fig. 2D

Community garden on Solidarności Avenue in the Praga district of Warsaw, maintained by activists from the local center for culture 


\section{The garden as a trademark of "green intervention" into city landscapes}

Do green areas in a city really have to be considered in opposition to a garden? After all, the nineteenth-century green areas in London, Paris, or Warsaw were gardens as well-filled with flowers, meticulously tended shrubbery, regularly planted trees, pots with agave and palm trees, as well as fountains.

The people of Brasilia use a word they coined, brasilite, to denote a sense of alienation and being lost in their orderly city full of immaculate, open-spaced green areas, a city which had been built from scratch by the famed modernist architect Oscar Niemeyer (Montgomery 2015, 135). As for Europe, the greenery of the earlier modernist developments can hardly be considered successful, though its potential is imposing. Today, its remnants are treated as empty spaces which, if they cannot be infilled, provide room for participatory budgeting projects. ${ }^{2}$ No one would dare proceed likewise with a well-tended garden; thus, artists took advantage of that image-an efficacious tool of manifesting right to urban space-readily developing what might be described as gardens within the perimeters of urban greenery. One of the most well-known examples of such projects is undoubtedly Joanna Rajkowska's Dotleniacz, a relatively small temporary garden with apond and fountain situated in Grzybowski Square, which are in turn surrounded with "garden-like" flower beds. In 2007, the feature attracted a lively community which solicited the city authorities to leave it there permanently.

Iga Kołodziej, a landscape architect who placed boxes with garden plants in front of the Praga Museum of Warsaw, not only made up for the lack of greenery, which had been clearly overlooked by the designers of the building, but also pointed to the need for a humanized public space. She did so by introducing plants that tend to be associated with a household garden; after all, they require daily care, interaction between the world of nature which they represent and the world of culture. A similar quality characterized the gardenly flowerbeds on the embankment of the Vistula, which were put in place in the summer of 2009 on the initiative of Klara Kopcińska as part of TransFORM, a project targeting the banks of the river.

If greenery on the premises of a house becomes a garden, why should roadside greenery, for instance, not be considered a garden? It is a garden too, with the exception that the staff of the Municipal Roads Authority are the "gardeners." In the central reservation along Aleja Niepodległości, Dolina Służewiecka or ul Wawelska,

2 In spring 2017, courtesy of the Parks and Green Spaces Authority in Warsaw, I had the pleasure to become acquainted with projects submitted for participatory budgeting. Most of the suggested investments, such as open-air gyms or smog-free towers were to be carried out in green areas. I also had the opportunity to talk with urban activists who advocated that playgrounds, dog paddocks, sports fields, etc., be situated on lawns at housing developments and in the city. Proposals for the creation of flowerbeds or community gardens were numerous as well. Clearly, the inhabitants believe that these areas are empty and represent little value; therefore, they may be treated as space for new projects. 


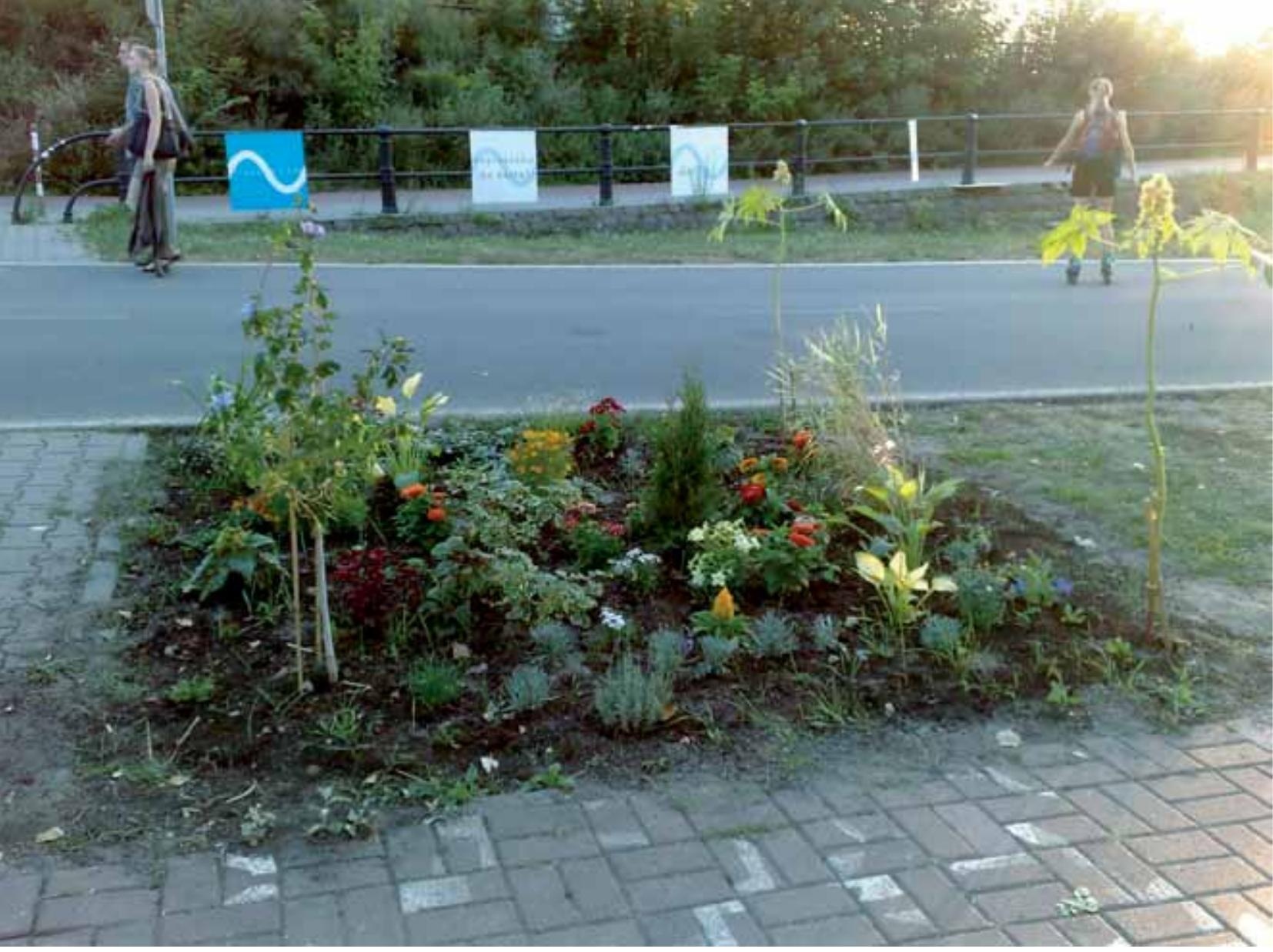

Fig. 3B

One of the TransFORM works by Klara Kopcińska on the Vistula (2007) 


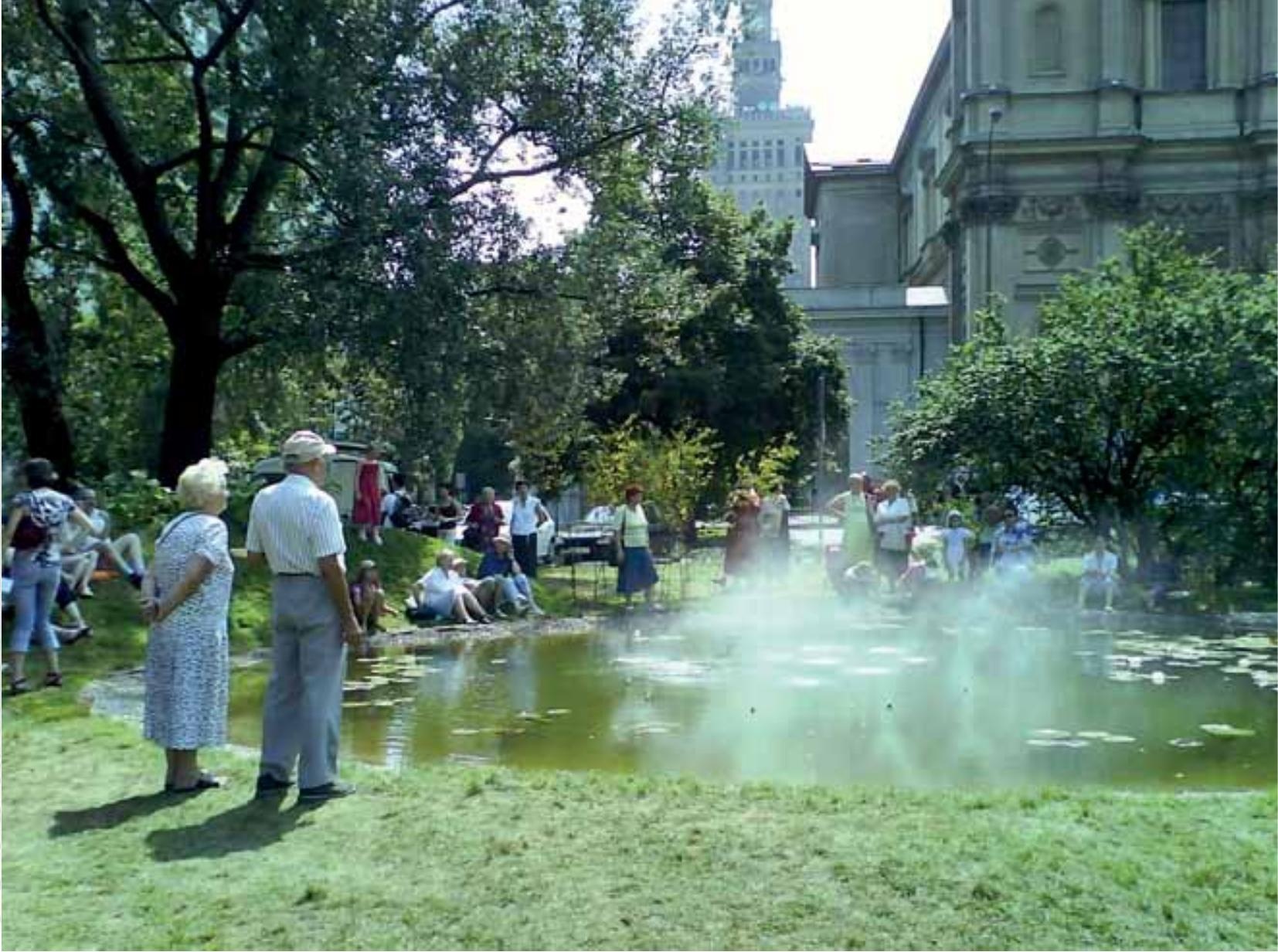

Fig. 3C

Dotleniacz (Oxygenerator) by Joanna Rajkowska (Warsaw) 
American and the English understanding of landscape. According to the author, when Americans speak of landscapes, what they have in mind is wilderness where the evidence of human presence is minimized, and preferably non-existent. In the eyes of the English, it resembles a garden; it is humanized and only as such does it appear aesthetic. In Poland, on the other hand, one hears the echoes of both understandings of landscape, especially where the city is concerned. When asked what is needed to make the landscape of a city beautiful, inhabitants of Tomaszów Mazowiecki answered "more greenery," while beautiful greenery in their opinion was one which is tended (i.e., sheared, pruned, and adequately managed) reflecting the touch of a gardener's hand. ${ }^{3}$ However, faced with the choice between various visions of greenery in their area-from regular flowerbeds among neatly cut hedges and mowed lawns, through naturally growing trees and meadows, to urban wasteland filled with synanthropic plants-they found each beautiful in its own way and having its own due place. Closer to buildings, they preferred a landscape resembling a garden, and more natural and "wild" greenery farther away from them. Urban landscape seems therefore to be comprehended as a continuum comprising the garden and the wilderness alike.

The garden context of the city landscape is thus urban wasteland abutting the gardens of housing developments as a continuation of green areas. In the structure of inhabited space, the undeveloped area is an equal element of the garden, on a par with the garden making up the social facade and the utilitarian garden proper (Gawryszewska 2008).

Itis therefore no surprise that residents feel at ease in such areas, treating them as natural recreation grounds that accompany their dwellings, where the constraints and pressures of everyday life fade away. This freedom of use is of paramount importance for the inclusion of those areas in a system of third places, informal territories of recreation, which are as necessary in the structure of inhabited spaces as homes andworkplaces are (Łepkowski and Wilczyńska 2016; Oldenburg 1996/1997).

At the Fort Służew housing estate, the residents developed the nearby grounds by building an informal park there, with banks, tables, places for bonfires, and ornamental trees they planted. In a seemingly abandoned wasteland, one often encounters seating of sorts, fashioned from waste material found in the vicinity, and in the wasteland terrain at the feet of what is known as the Warsaw embankment, people have made unofficial trails for mountain bikes. The users are clearly content with minimal development, which enables the previous, informal character of the wasteland to be preserved.

This observation was taken advantage of by Marek Piwowarski with a team of officers from the Municipal Property Board, who built a promenade for pedestrians

3 Results of ca. 120 interviews with inhabitants of Niebrów in Tomaszów Mazowiecki, conducted as part of the Modernization Project for the 1939 Defenders of Tomaszów Mazowiecki Housing Estate, developed by Beata J. Gawryszewska, Anna Wilczyńska, Maciej Łepkowski, Ewa Zielińska, and Dariusz Śmiechowski, November 2016-May 2017. 


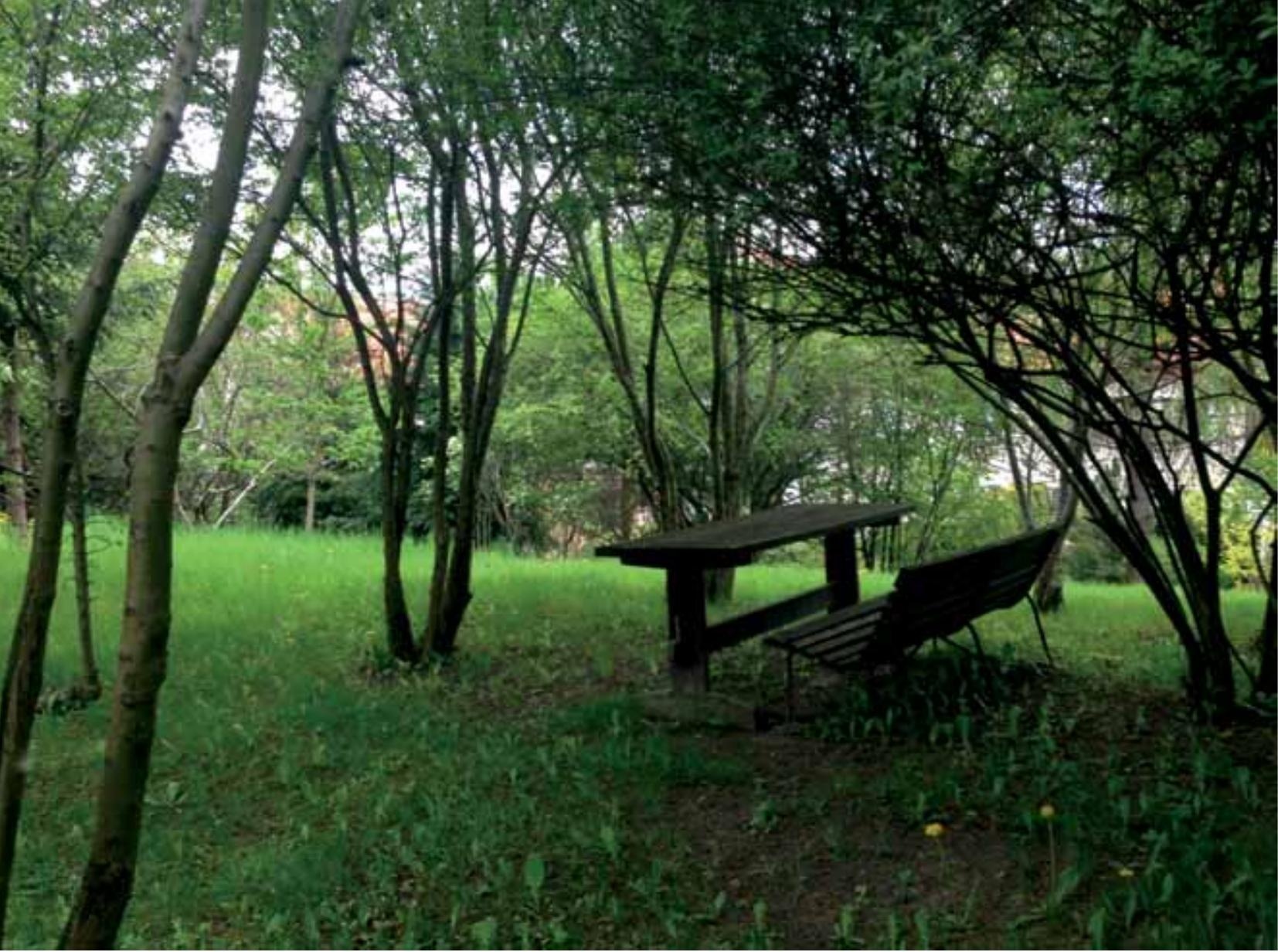

Fig. 4

Wasteland development.

A

Park created by residents of the Fort Służew housing estate in Warsaw 


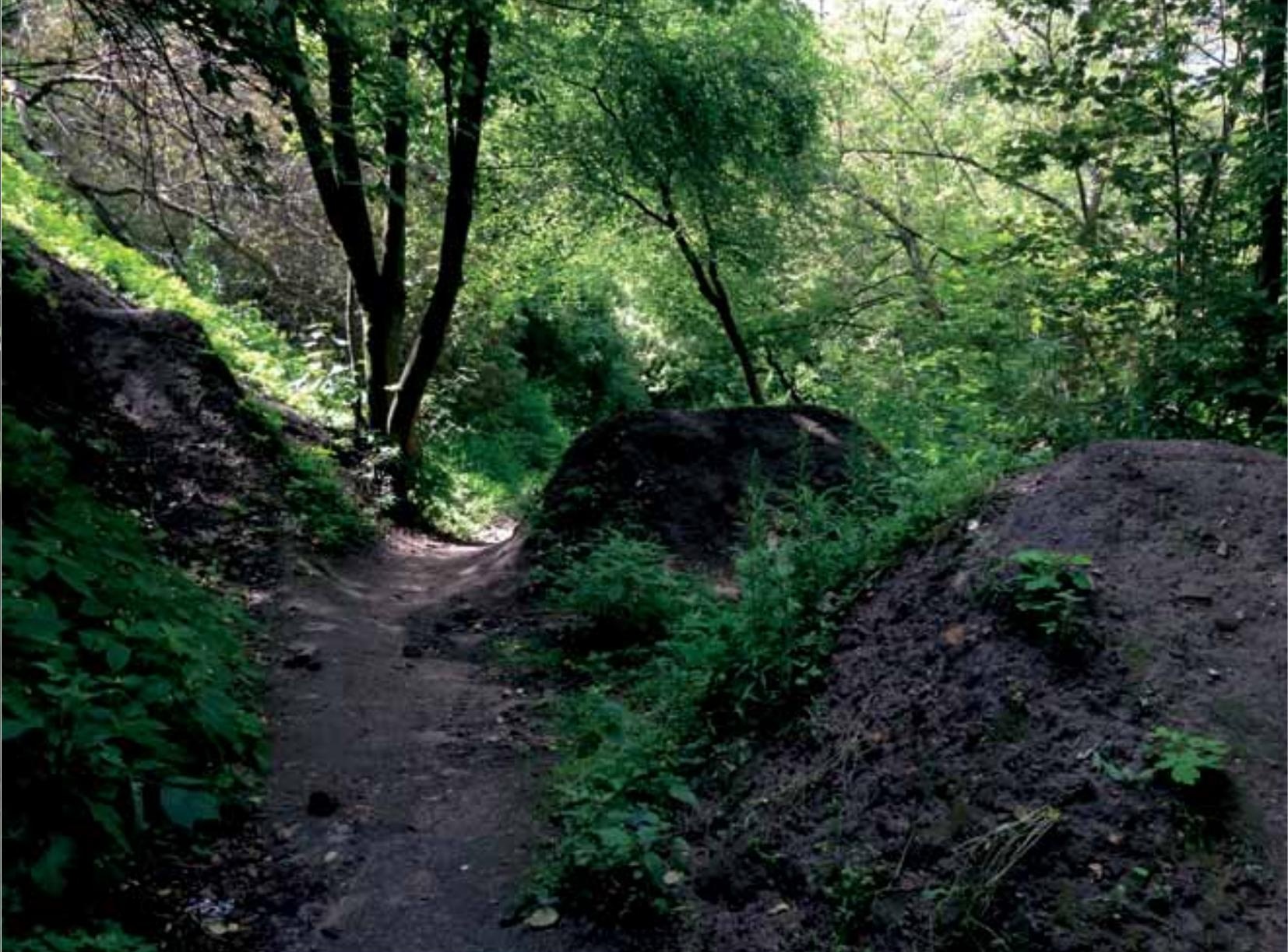

Fig. 4B

Unofficial bicycle track on Piaseczyńska Street in Warsaw 


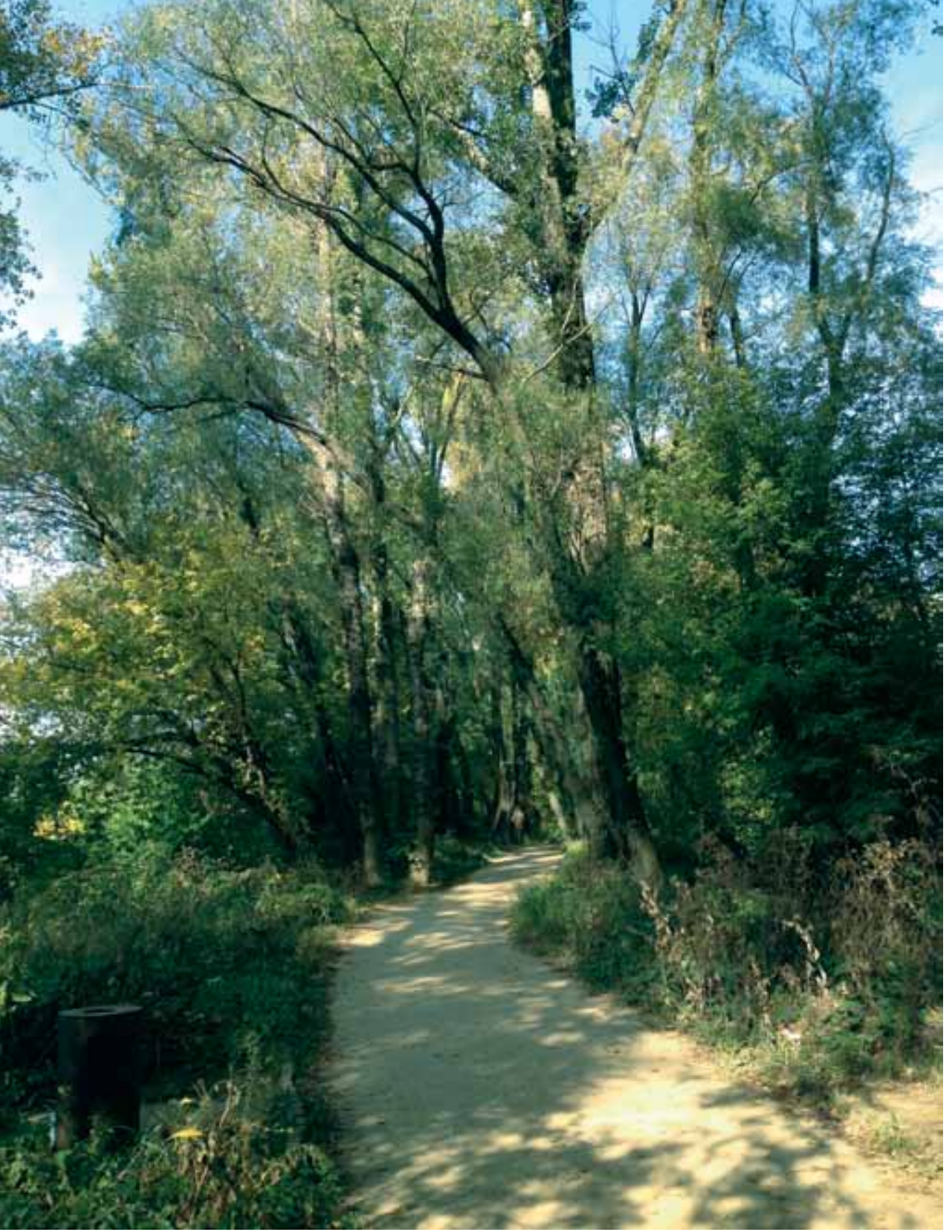

Fig. 4D

Bicycle lane in the Praga district of Warsaw 
and cyclists along the right bank of the Vistula in the semi-natural habitat of the Vistulan wetland which constitutes a Natura 2000 area. Along the ca. 8.5-kilometer path-which enjoys great favor among Varsovians-no new plants were planted; the only new feature was a water-permeable surface laid on the route, which imitates sand from the Vistula. The obtained effect enables users to feel very close to nature, while at the same time ensuring their safety with a "civilized" path whose visual aspect is additionally well-set in culture.

\section{Greenery as a tool in the contest for the city}

Among modern theories of urban planning, the idea of everyday landscape conceived by John Chase, Margaret Crawford, and John Kaliski stands out in particular (2008). The concept allows for everyday activities of the inhabitants which add to the overall picture of city, such as the laundry they hang out to dry or the stalls of street vendors. It is on them that the character of the city hinges rather than on grand urbanism.

The authors of the notable project entitled Niewidzialne miasto [Invisible city] also look for new manifestations of democracy in simple forms originating directly with the inhabitants, as they prove "that the city lives, and does so thanks to its residents, who do not merely 'use' but co-create it, leaving diverse imprints of their activity in its space" (Krajewski 2013, 13).

Gardens fit into that definition by all means. From minute gardens under one's windows in extensive housing estates, through flowerbeds planted by activists in apple crates, to seemingly random rows of flowers amidst lawns, the image of the garden-evoking close relationships and connoting developed, inhabited spaceis used to forge a new landscape of the city where the inhabitants begin to shape its character. What is more, there are no losers in this contest. The garden, used by artists, landscape architects, and officials may become an effective tool in defending public green areas against the pressure of structural development, animating urban populations, improving relationships within it, and even fostering creative attitudes.

\section{References:}

Berleant, Arnold. 1997. Living in the Landscape: Toward an Aesthetics of Environment. Lawrence: University Press of Kansas.

Chase, John L., Margaret Crawford, and John Kaliski. 2008. Everyday Urbanism. New York: Monacelli.

Cosgrove, Denis E. 2014. "Krajobraz i europejski zmysł wzroku—przyglądanie się naturze" ["Landscape and the European Sense of Sight_Eyeing Nature"]. Translated by Beata Frydryczak. In Krajobrazy. Antologia tekstów [Landscapes: An Anthology], edited by Beata Frydryczak and Dorota Angutek, 79-110. Poznań: Wydawnictwo PTPN 
Bellini, Amadeo. 1992. "Difficoltà teoriche nel restauro dei giardini storici." In // giardino e il tempo. Conservazione e manutenzione delle architetture vegetall, edited by Maurizio Boriani and Lionella Scazzosi. Milano: Guerini e Associati.

Foster, Sheila. 2016. "The Co-City: From the Tragedy to the Comedy of the Urban Commons." The Nature of Cities (blog). November 2. http://www.thenatureofcities.com/2016/11/02/the-co-city-fromthe-tragedy-to-the-comedy-of-the-urban-commons/?utm _ source=feedburner\&utm _ medium=email\&utm _ campaign=Feed\%3A+TheNatureOfCities+\%28The+Nature+of+Cities\%29.

Gawryszewska, Beata J. and Łukasz Guzek. 2002. "Ogród rodzinny i performance" ["Family Garden and Performance]. Przyroda i miasto 4: 101—5.

Gawryszewska, Beata J. 2004. "Modernizować modernizm? Zielone dziedzińce Czerwonego Żoliborza w programie rewitalizacji przestrzeni społecznej osiedla WSM" ["Is Modernism to Be Modernised? Green Yards of Red Żoliborz in the Program for Revitalizing Social space at the WSM district"]. Przyroda i miasto 6: 57-72.

Gawryszewska, Beata J. 2008. Historia i struktura ogrodu rodzinnego[The History and Structure of the Family Garden]. Warsaw: SGGW.

Gawryszewska, Beata J. 2013. Ogród jako miejsce w krajobrazie zamieszkiwanym [The Garden as a Place in an Inhabited Landscape]. Warsaw: Wieś Jutra.

Gawryszewska, Beata J. and Izabela Myszka-Stąpór. 2016. "Ogrody towarzyszące zamieszkiwaniu w procesach rewitalizacji i redefiniowaniu przestrzeni miejskich" ["Gardens Accompanying Habitation in Revitalizing Processes and Redefining Urban Spaces"]. Prace Komisji Krajobrazu Kulturowego 32: $71-82$.

Harvey, David. 2012. Rebel Cities: From the Right to the City to the Urban Revolution. London: Verso. Jackson, John B. 1984. Discovering the Vernacular Landscape. New Haven: Yale University Press. Krajewski, Marek. 2013. Niewidzialne miasto [Invisible City]. Warsaw: Fundacja Bęc Zmiana.

Latour, Bruno. 2009. Polityka natury [Politics of nature]. Translated by Agatha Czarnacka. Warsaw: Wydawnictwo Krytyki Politycznej.

Łepkowski, Maciej, Ryszard Nejman, and Anna Wilczyńska. 2016. "The Role of Green Urban Wastelands in 3rd Place Creation: Challenge for Urban Policy in Poland". In Landscapes and Greenways of Resilience, Proceedings of $5^{\text {th }}$ Fabos Conference on Landscape and Greenway Planning, edited by Sándor Jombach, IstvánValanszki, Krisztina Filep-Kovacs, Julius Gy. Fabos, Robert L. Ryan, Mark Lindhult and LászlóKollanyi, 45-53. Budapest: Szent István Egyetem.

Montgomery, Charles. 2015. Miasto szczęśliwe. Jak zmienić nasze życie, zmieniając nasze miasta [Happy City: Transforming Our Lives Through Urban Design]. Translated by Tomasz Tesznar. Kraków: Wydawnictwo Wysoki Zamek.

Myszka-Stąpór, Izabela and Beata J. Gawryszewska. 2013. "Logicznie i symbolicznie. O projektowaniu proaktywnym w Bolestraszycach" ["Logically and Symbolically: On Proactive Design in Bolestraszyce"]. Sztuka ogrodu. Sztuka krajobrazu 1 (5): 113-9.

Oldenburg, Ray. 1996/1997. "Our Vanishing 'Third Places.". Planning Commissioners Journal 25: 6-10.

Prominski, Martin. 2016. "Designing Landscapes as Evolutionary Systems." The Design Journal 8 (3): 25-34. 
Beata J. Gawryszewska

Salwa, Mateusz. 2016. Estetyka ogrodu. Między sztuką a ekologią [Garden Aesthetics: Between Art and Ecology]. Łódź: Przypis.

Szafrańska, Małgorzata. 2011. Człowiek w renesansowym ogrodzie [Man in a Renaissance Garden]. Kraków: Miniatura.

Rymkiewicz, Jarosław. 2010. Myśli różne o ogrodach [Thoughts on Gardens]. Warsaw: Wydawnictwo Sic!

Winiarska-Lisiecka, Edyta Z. 2016. Podwórka jako ogrody wspólnot sąsiedzkich [Yards as Neighbors' Community Gardens]. PhD diss., Warsaw University of Life Sciences. 